\title{
Interactive Multimedia as a Guidance for Adherencing to Maintain Fitness for High School Students
}

\author{
$1^{\text {st }}$ Masrurdin Ilmi \\ Physical Education, Health and \\ Recreation \\ State University of Malang \\ Malang, Indonesia \\ masrurdin25@gmail.com
}

\author{
$2^{\text {nd }}$ Ari Wibowo Kurniawan \\ Physical Education, Health and \\ Recreation \\ State University of Malang \\ Malang, Indonesia \\ ari.wibowo.fik@um.ac.id
}

\author{
$3^{\text {nd }}$ Febrita Paulina Heynoek \\ Physical Education, Health and \\ Recreation \\ State University of Malang \\ Malang, Indonesia \\ febrita.paulina.fik@um.ac.id
}

\begin{abstract}
The objective to be achieved in this research is to describe students' motivation in attending PE education in Bali and East Java. The data analysis method uses quantitative analysis and is processed into descriptive statistics, namely percentage and mean analysis. Intrinsic Motivation results get a percentage for Singaraja 23.3\%, and Malang was $24.9 \%$. Identified Regulation Singaraja was $23.4 \%$, for Malang was $24.1 \%$. The Introjected Regulation of Singaraja was $19.6 \%$, and Malang City is $19.1 \%$. External Regulation of Singaraja is $20.1 \%$, for Malang was $19.2 \%$. Amotivation of Singaraja is $13.6 \%$, for Malang was $12.7 \%$. The conclusion was that students' motivation in Malang, East Java, was higher in Intrinsic Motivation and Identified Regulation indicators.
\end{abstract}

Keywords—physical education, motivation.

\section{INTRODUCTION}

Physical education is an education in which the knowledge provided is in the form of physical activities and tends to be carried out outside the classroom, physical education is also a medium for encouraging motor development, physical development, sportsmanship, habituation of healthy lifestyles and character building.

Physical education is also a means of mental training, potential development, increasing physical activity and a means of socializing for the development of attitudes and character. In physical education there are many types of activities that can be done, one of which is doing physical fitness activities. According to [1] physical fitness is an individual's ability to perform physical activity properly without experiencing significant fatigue. According to [2] in essence, physical education is an educational process that focuses on physical activity and health in producing changes to a person, both from physical, mental, and emotional aspects. Meanwhile, according to physical education is a form of education that is structured systematically in order to improve the quality of the individual as a whole both in terms of cognitive, affective and psychomotor.

Physical fitness, the element of flexibility, plays an important role to be developed considering that flexibility is one of the components of physical fitness besides endurance, agility, speed and balance. According to [3] Flexibility can be defined as the ease of movement, especially those that occur in muscles and joints. According to [4] physical fitness is a physical ability and ability to adapt to daily activities without significant excessive fatigue. The absence of meaningful fatigue is when someone who has done certain activities is still able to do other activities with enthusiasm and can enjoy his free time. Meanwhile, according to [5] physical fitness is a person's ability to carry out productive activities everyday without feeling excessive fatigue and still have energy reserves to enjoy his free time well or do sudden activities.

In an era like today, the learning process using technology, one of which is interactive multimedia which is very necessary and necessary to be needed and developed, because it can help teachers and students to provide or understand the material. According to [6] "multimedia is a combination of various media '(file format) in the form of text, graphics, audio, and interaction and is used to convey messages or information from the sender to the recipient of the message or information". It can be interpreted that multimedia is a combination (file format) in the form of video, text, interaction graphics and audio used to give messages. In fact, teachers of physical education, sports and health rarely apply and make interactive multimedia in learning, one of which is physical fitness learning, the element of flexibility, so that students easily feel bored because the attractiveness of students to take part in learning is low. Media is anything that can be used to convey 
messages from sender to recipient so that it can stimulate student interest and attention in such a way [7] According to [8] learning media is a means of carrying information that can be used for learning purposes. Learning media is a physical means of conveying material in learning activities in the form of print (hardware) or listening point of view (software). Meanwhile, according to [9] media is something that can deliver messages or information from the message source (message giver) and message recipients. Media is something that can be used in the process of procuring information.

Based on the results of preliminary observations of the research, which was carried out by researchers on that date in the form of a needs analysis carried out by researchers with observations and questionnaires with the number of subjects 100 students at SMA Negeri 1 Turen obtained results in the form of $90 \%$ of students getting material fitness elements of flexibility from the media in the form of delivery. material from student worksheets and teaching materials, $80 \%$ of students have never or have never received learning using interactive multimedia physical fitness with interactive multimedia so that the assumptions of researchers reveal that students in learning physical fitness material flexibility require interactive multimedia, and only $15 \%$ students get physical fitness material flexibility elements from the media in the form of videos, independent learning activity units and powerpoints.

From the results of previous research, there are advantages of the product that will be developed by the researcher, namely the physical fitness learning process, the flexibility element can be done using a supporting tool in the form of a laptop without having to be online or connected to the internet first to get the material, so that the media developed by researchers is suitable for schools in the region -specific area. In rural areas it is generally difficult to access media that must be connected to the internet first. With the interactive multimedia developed by researchers, it is easier for teachers to deliver physical fitness material for flexibility and students are more interested in participating in learning activities, because in this development product contains material for physical fitness elements of flexibility that are complete and accompanied by learning videos in the form of variations interesting exercise. This product is made with the aim of increasing student interest in learning and learning achievement.

\section{METHOD}

The research method used is multimedia development developed by [10] using the following steps: 1) needs analysis, 2) doing product design, 3) development, 4) implementation, and 5) evaluation or evaluation. In this method, researchers used a subject as many as 100 students of class X and XI. In addition, the formula used to process data is a percentage qualitative descriptive analysis can be described as follows:

Information:

$$
V=\frac{T S E V}{S-\max } \times 100 \%
$$

$\mathrm{V}=$ Validity

TSEV = Total Empirical Validator Score

$\mathrm{S}-\max =$ Maximum Expected Score
$100 \%=$ Constant Number

\section{RESULT}

Data analysis was carried out based on the results of small group trials of Class X students and Class XI students, each of these aspects will be explained through the following tables:

TABLE I. Results of SMALl GROUP TRIAL DATA ANALYSiS CLASS X WITH N $=10$

\begin{tabular}{cccl}
\hline NO & ASPECT & FEASIBILITY & CATEGORY \\
\hline 1 & Aspect Of Clearity & $84 \%$ & Enough Valid \\
2 & Use Aspects & $82 \%$ & Enough Valid \\
3 & Easy Aspect & $81 \%$ & Enough Valid \\
4 & Aspect Of Conformity & $84 \%$ & Enough Valid \\
5 & The Entertainment Aspect & $74 \%$ & Enough Valid \\
\hline & Average & $81 \%$ & Enough Valid \\
\hline
\end{tabular}

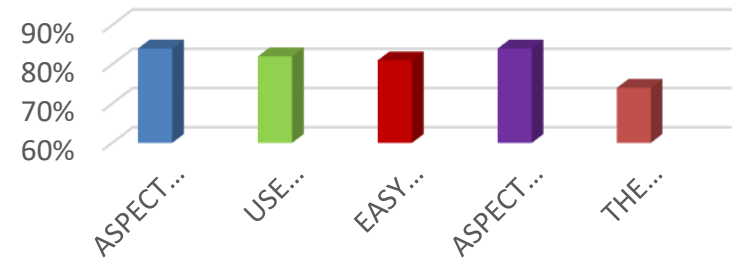

Based on the results of the analysis in the table, the data was obtained from trials in a small group of class X students at SMA Negeri 1 Turen with a percentage of $81 \%$, it was obtained based on several aspects. Then these results are converted based on the feasibility classification table which shows that the development of physical fitness learning development elements based on interactive multimedia has met the very valid criteria and is suitable for use.

TABle 2. Results of SMall Group Trial Data ANAlysis CLASS XI

\begin{tabular}{cccc}
\hline NO & ASPECT & FEASIBILITY & CATEGORY \\
\hline 1 & Aspect Of Clearity & $83 \%$ & Enough Valid \\
2 & Use Aspects & $88 \%$ & Very Valid \\
3 & Easy Aspect & $86 \%$ & Enough Valid \\
4 & Aspect Of Conformity & $84 \%$ & Enough Valid \\
5 & The Entertainment Aspect & $78 \%$ & Enough Valid \\
\hline & Average & $84 \%$ & Enough Valid \\
\hline
\end{tabular}

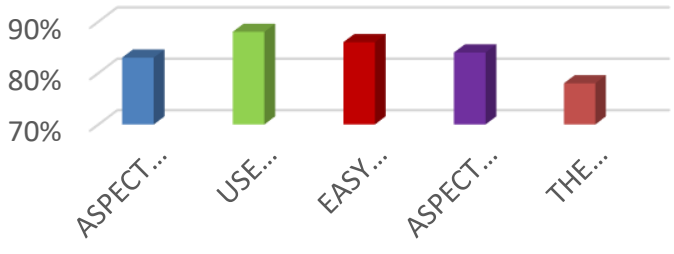

Based on the results of the analysis in the table, the data was obtained from trials in a small group of class XI students at SMA Negeri 1 Turen with a percentage of $84 \%$, it was obtained 
based on several aspects. Then these results are converted based on the feasibility classification table which shows that the development of physical fitness learning development elements based on interactive multimedia has met the very valid criteria and is suitable for use.

The results of the trial data analysis in a large group with the help of 60 students, there were 30 students of class X and 30 students of class XI based on the aspects that included; aspects of clarity, aspects of usability, aspects of convenience, aspects of suitability and aspects of attractiveness in development and learning products of physical fitness elements of flexibility based on interactive multimedia are presented in the following table:

TABle 3 Results of Class X Large Group Trial Data ANALYSIS

\begin{tabular}{cccc}
\hline NO & ASPECT & FEASIBILITY & CATEGORY \\
\hline 1 & Aspect Of Clearity & $80 \%$ & Enough Valid \\
2 & Use Aspects & $81 \%$ & Enough Valid \\
3 & Easy Aspect & $81 \%$ & Enough Valid \\
4 & Aspect Of Conformity & $77 \%$ & Enough Valid \\
5 & The Entertainment Aspect & $73 \%$ & Enough Valid \\
\hline & Average & $78 \%$ & Enough Valid \\
\hline
\end{tabular}

Based on the results of data analysis obtained from the results of trials in a large group of class $X$ at SMA Negeri 1 Turen showed a percentage of $78 \%$, these results were obtained based on several aspects. So that these results can be converted based on the feasibility classification table which can show that the development and learning products of physical fitness elements of flexibility based on interactive multimedia have met the criteria so that the data is very valid and suitable for use.

TABle 4. Results of Class XI LARGE GROUP Trial DatA ANALYSIS

\begin{tabular}{cccc}
\hline NO & ASPECT & FEASIBILITY & CATEGORY \\
\hline 1 & Aspect Of Clearity & $84 \%$ & Enough Valid \\
2 & Use Aspects & $87 \%$ & Very Valid \\
3 & Easy Aspect & $85 \%$ & Enough Valid \\
4 & Aspect Of Conformity & $83 \%$ & Enough Valid \\
5 & The Entertainment Aspect & $77 \%$ & Enough Valid \\
\hline \multicolumn{4}{r}{} \\
\hline
\end{tabular}


flexibility of the body in order to reduce the occurrence of injury. Agree with [11] flexibility can be defined as the maximum range of motion that can be exercised in joints, namely the extent to which movement can occur in joints without undue strain (injury).

According to [12] interactive multimedia is a learning model that can be used as a medium in channeling messages so that it can stimulate feelings, thoughts, attention and encouragement to students in the learning process. Meanwhile, according to [13] interactive multimedia is a combination of animation, graphics, digital text, images, audio and video by providing an interactive control. The use of interactive multimedia itself is expected to help the learning process of teachers and attract participants. students in following the ongoing material. This statement is in accordance with research [14] that interactive multimedia is able to help teachers deliver material in each learning process, so that students are able to understand the material presented by the teacher quickly. It is hoped that with the creation of the development of physical fitness learning, the elements of flexibility based on interactive multimedia can increase the motivation and interest of students and can add teacher references as a reference for teaching materials in the physical fitness learning process on the elements of flexibility.

Previous research by [15] shows that using interactive learning through multimedia will be more effective to improve students' critical thinking skills and ways. There is an increase in the ability to think critically by students, after using interactive multimedia it can show that interactive multimedia has an effect on increasing students' thinking. Previous research by [16] shows that using media in the learning process can make someone learn the material in a more effective and efficient way, so that the material that has been delivered can be mastered quickly and correctly.

\section{CONCLUSION}

Based on the results of research on the development of physical fitness learning media for flexibility based on interactive multimedia in SMA Negeri 1 Turen, a useful product was produced for learning physical fitness for flexibility based on interactive multimedia.

\section{REFERENCES}

[1] S. Nurrochmah, Tes dan Pengukuran Dalam Pendidikan Jasmani \& Keolahragaan. Malang: UM PRESS, 2016.
[2] J. S. Husdarta, Manajemen Pendidikan Jasmani. Bandung: Alfabeta, 2011.

[3] G. Wiarto, Fisiologi dan Olahraga. Yogyakarta: Graha Ilmu, 2013.

[4] Muhajir, Pendidikan Jasmani, Olahraga dan Kesehatan. Bandung. Erlangga, 2014

[5] Roji, Pendidikan Jasmani Olahraga dan Kesehatan. Jakarta: Erlangga, 2009.

[6] A. . Kurniawan, "Multimedia-Based Learning Model for Gymnastics Skills," 2019.

[7] A. S. Sadiman and Dkk, Media Pendidikan Pengertian, Pengembangan, dan Pemanfaatannya. Jakarta: PT. Raja Grafindo Persada, 2011.

[8] Rusman, Belajar dan Pembelajaran Berorientasi Standar Proses Pendidikan. Jakarta: Kencana, 2017.

[9] Dwiyogo, Aplikasi Teknologi Pembelajaran: Media Pembelajaran Penjas \& Olahraga. Malang: UNIVERSITAS NEGERI MALANG., 2008

[10] W. Lee and D. Owens, Multimedia Based Instructional Design: Computer Based Training Web Based Training Distance Broadcast Training Performance Based Solusions 2nd Ed. San Fransisco: Pfeiffer, 2004.

[11] J. Fisette and D. Wuest, Foundation of Physical Education. New York: McGraw-Hill Education, 2018.

[12] Munir, Multimedia Konsep \& Aplikasi Dalam Pendidikan. Bandung: Alfabeta, 2015.

[13] B. E. Purnama, Konsep Dasar Multimedia. Yogyakarta: Graha Ilmu, 2013.

[14] Baharuddin, "Pengembangan Media Pembelajaran Berbasis Multimedia Interaktif Sekolah Menengah Kejuruan Terhadap Efektif dan Efisiensi Pembelajaran," J. Inov. Dan Teknol. Pembelajaran., 2015.

[15] S. Husein, L. Herayanti, and G. Gunawan, "Pengaruh Penggunaan Multimedia Interaktif Terhadap Penguasaan Konsep dan Keterampilan Berpikir Kritis Siswa pada Materi Suhu dan Kalori,' J. Pendidik. Fis. Dan Teknol., 2017.

[16] A. W. Kurniawan, "Pengembangan Pembelajaran Judo Teknik Bantingan Kyu 4 dengan Media VCD untuk Pejudo PJSI (Persatuan Judo Seluruh Indonesia)," Pertem. Ilm. Ilmu Keolahragaan Nas., pp. 25-37, 2014. 